\title{
WestVirginiaUniversity
}

THE RESEARCH REPOSITORY @ WVU

West Virginia Agricultural and Forestry Experiment

Davis College of Agriculture, Natural Resources

Station Bulletins

And Design

$1-1-1976$

\section{Comparison of fresh markets for West Virginia apples}

Robert L. Jack

Follow this and additional works at: https://researchrepository.wvu.edu/ wv_agricultural_and_forestry_experiment_station_bulletins

\section{Digital Commons Citation}

Jack, Robert L., "Comparison of fresh markets for West Virginia apples" (1976). West Virginia Agricultural and Forestry Experiment Station Bulletins. 648.

https://researchrepository.wvu.edu/wv_agricultural_and_forestry_experiment_station_bulletins/550 @ WVU. It has been accepted for inclusion in West Virginia Agricultural and Forestry Experiment Station Bulletins by an authorized administrator of The Research Repository @ WVU. For more information, please contact ian.harmon@mail.wvu.edu. 
Blank Page in Original Bulletin 


\section{SUMMARY}

Commercial apple production in the United States increased slightly from 1965 through 1973 and Appalachian District producers (Maryland, Pennsylvania, Virginia, and West Virginia) continued to account for 19 to 20 percent of total United States production.

Cities in the Eastern, Midwestern, and Southern markets received an average of 60,12 , and 28 percent, respectively, of the reported unloads from the District in 1965-73. Virginia was the only state in the District that unloaded more apples in the Southern than in the Eastern market. There appeared to be a trend developing for the Appalachian District to decrease shipments in the Eastern and increase them to the Southern and Midwestern markets.

The largest number of annual unloads in the Eastern market occurs in Philadelphia, followed by Pittsburgh, Washington, and Baltimore, respectively.

Baltimore is the most important market for reported unloads of West Virginia apples; the state accounts for approximately 26 percent of the total.

In all four cities average monthly unloads reach a peak in October and then decline through June. Reported unloads from the Appalachian District and West Virginia also peak in October and then decline. In most cases, unloads for the four cities from other production areas such as Washington and New York reach a low in August or September and then peak in May.

Of the four cities studied average annual per capita unloads were highest for Pittsburgh and lowest for Washington, D. C. The trend of per capita unloads in all markets has been downward since 1969 with the fastest rate of decline in Baltimore and the slowest in Washington, D. C. Monthly per capita unloads reach a peak in all four markets in October and tend to decline through July. The greatest difference between average maximum and minimum unloads usually occurs in September or October while the smallest variation occurs in July or August.

Estimated average annual retail price per pound of apples in the four cities almost doubled between 1965 and 1973. Prices in all markets showed similar patterns but the average Pittsburgh prices were well below retail prices in the other three cities. Average monthly retail prices showed the expected seasonal pattern with a peak in August and the low point in October or November. 


\section{ACKNOWLEDGMENT}

This bulletin is published as a contribution to the Northeast Regional Marketing Research Project (NE-88). The West Virginia research for this publication was supported by both state and regional research funds.

\section{THE AUTHOR}

Robert L. Jack is Agricultural Economist.

West Virginia University

Agricultural and Forestry Experiment Station

College of Agriculture and Forestry

Dale W. Zinn, Director

Morgantown 


\title{
Comparison of Fresh Markets for West Virginia Apples
}

\author{
Robert L. Jack
}

West Virginia ranked seventh in the nation during $1969-71$ as an appleproducing state. The state's production is divided almost equally between the fresh and processing markets.

Each year, apples from West Virginia are reported as carloads in fresh markets throughout the United States. ${ }^{1}$ However, Baltimore, Washington, D. C., Pittsburgh, and Philadelphia, in rank order, are the major markets and normally account for 90 percent of the unloads. West Virginia apples compose approximately 30 percent of the reported apple unloads in Baltimore, 10 percent in Pittsburgh and Washington, D. C., and 7 percent in Philadelphia. Competition from other producing regions in these four fresh apple markets varies from year to year and from month to month within a particular year. This variation in competition, along with a continued decline in per capita fresh apple consumption, justifies market analysis research which can be helpful to producers and brokers in obtaining the highest return possible for apples produced in West Virginia.

\section{PURPOSE}

The purpose of this study is to analyze unloads, consumption, and price of fresh apples over a nine-year period (1965-73) in the Baltimore, Pittsburgh, Philadelphia and Washington, D. C. markets. This information can help the West Virginia producers make marketing decisions for increased returns.

\section{PROCEDURE}

\section{Unloads}

Monthly unloads by origin of apples in the four markets from July 1965 to June 1973 were taken from: Fresh Fruit and Vegetable Unloads in Eastern Cities and Marketing Appalachian Apples-Season Summaries. The reported unloads were used to compute monthly, yearly, and cumulative totals, averages, and percentages for the nine years being studied.

${ }^{1}$ Until January 1971 a carload contained 820 cartons of apples weighing 40 to 45 pounds each. After January 1971, a carload contained 900 cartons weighing 40 to 45 pounds each. In this publication, carload and unload will be used interchangeably. 


\section{Pounds}

Pounds of apples unloaded for each month and for each year were computed by converting carloads to cartons and cartons to pounds. From July 1965 to January 1971 a carload contained 820 cartons weighing 40 to 45 pounds each. By using 42.5 pounds per carton, a carload contained 34,850 pounds. From January 1971 to the present a carload contained 900 cartons weighing 40 to 45 pounds, or 38,250 pounds using 42.5 pounds per carton.

\section{Population}

Population figures for the nine years under study were estimated since population census is only published every ten years. For example, the reported Baltimore population for census years 1960 to 1970 was used to determine the average annual increase of 1.48 percent, or 26,695 people per year, between these two census years. The following population estimates were obtained:

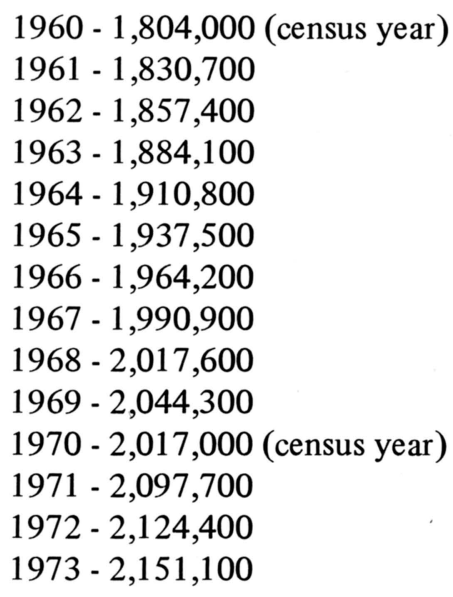

The populations for Pittsburgh, Philadelphia, and Washington, D. C. were computed the same way.

\section{Pounds Per Capita}

Pounds per capita were computed by dividing pounds of apples unloaded each month and each year by the estimated annual population for each city. The author realizes that all apples reported as unloads were not consumed in the four cities. However, the proportion not consumed in the city would likely be small.

Year

In order for production and marketing of the crop to occur in the same time period, the analysis of unloads in this study is based on a fiscal year. That is, the year 1965 starts with July 1965 and continues through June 1966. 


\section{COMMERCIAL APPLE PRODUCTION}

\section{United States}

Commercial apple production in the United States from 1965 through the 1973 crop fluctuated from 5.4 billion pounds in 1967 to 6.8 billion pounds in 1969. Average annual production for the nine-year period was slightly less than 6.0 billion pounds (Figure 1). Apple production in the Appalachian District (Maryland, Pennsylvania, Virginia, and West Virginia) accounted for an average of 1.14 billion pounds per year, or approximately 19 percent of total U. S. production for the nine years. Data in Figure 1 show that the change in production in the U. S. and Appalachian District moved in the same direction six out of eight years. There appeared to be a very slight upward trend in commercial apple production in the U. S. and the Appalachian District from 1965 through 1973.

\section{Appalachian District}

Percentage figures by production areas in the Appalachian District show that each of the four states maintained approximately the same proportion of total apple production for the nine-year period (Figure 2). On the average, Pennsylvania accounts for 39 percent, Virginia for 36 percent, West Virginia for 19 percent, and Maryland for 6 percent of the average annual production in the District. Total production in the District showed an upward trend during the nine-year period.

\section{SHIPMENTS OF APPLES}

The Federal-State Market News Service reports unloads of fruits and vegetables in carlot equivalents by origin and for 41 cities in the United States. Apple unloads are part of these data. Prior to January 1, 1971, one carlot equivalent contained 820 boxes, or cartons weighing 40-45 pounds. After January 1, 1971, one carlot equivalent contained 900 boxes, or cartons weighing $40-45$ pounds. It can be assumed that 100 percent of the apples reported in the unload data are used for fresh consumption.

An examination of unloads over time can help identify (1) important markets, (2) changes in markets, and (3) major competitors within a market. Over the nine-year period from 1965-73 the Appalachian District shipped an average of 60 percent of its reported unloads to Eastern markets, 12 percent to the Midwestern markets, 28 percent to Southern markets, and less than 1 percent to Western markets (Figure 3). Except for Virginia, the Eastern market is the most important for unloads from the District. Pennsylvania unloads the highest proportion ( 80 percent) and Virginia unloads the lowest proportion (45 percent) in this market. There appears to be a downward trend in the percentage 
of unloads from each state participating in the Eastern market but an increase in the Midwestern and Southern markets.

\section{THE EASTERN MARKET}

Since the Eastern market receives more than 60 percent of the unloads reported from the Appalachian District, an analysis of unloads by city in the Eastern market and by state in the District can be useful in making marketing decisions.

The Eastern market includes the following cities: Albany, Baltimore, Boston, Buffalo, New York-Newark, Philadelphia, Pittsburgh, Providence, and Washington. A summary of average annual unloads from 1965 through 1973 by state in the District and by city in the Eastern market shows Philadelphia, Pittsburgh, and Washington are in the top four most important cities for each of the producing states in the District (Table 1). The most important city for West Virginia and Maryland is Baltimore, while Pittsburgh and New York-Newark are the most important for Pennsylvania and Virginia, respectively.

\section{Annual Unloads}

Baltimore. Unloads ranged from a low of 460 in 1973 to 900 in 1969 (Figure 4). As shown in Figure 1, the annual change in the unloads for Baltimore indicates a pattern positively related to annual production in the United States. In addition, the nine years of unload data indicate a downward trend in the Baltimore market, with 1973 unloads being 55 percent of the unloads in 1965 . Over the nine-year period under study, West Virginia accounted for an average of 26 percent of all unloads. There were only three years-1966, 1972, and 1973-in which another state, Washington, accounted for more unloads than did West Virginia. In 1966, production in the Appalachian District and West Virginia was below average, but in 1972 and 1973 production in these two areas was about average. There is a downward trend for the nine-year period in the number of unloads from West Virginia.

Washington, D. C. Unloads flucuated from a low of 790 in 1968 to 1,032 in 1969 (Figure 5). There appears to be no upward or downward trend in the number of unloads in Washington during the nine years from 1965 to 1973. For each of the nine years, the State of Washington supplied the largest proportion of the unloads, followed by Virginia and Pennsylvania, respectively. However, since 1969 Pennsylvania unloads in the Washington market have been greater than the unloads from Virginia. The proportion of unloads from West Virginia was relatively high from 1969-72 but dropped back to 8 percent in 1973 .

Pittsburgh. Unloads increased from 1,192 in 1966 to 1,458 in 1968 (Figure 6 ), but since 1968 they have declined each year to only 1,008 in 1973. For the nine-year period there is a downward trend. The major shippers are New York, Washington, and Pennsylvania, which account for 29, 25, and 22 percent of the 
TABLE 1

Average Annual Unloads by City in Eastern Market and by State in Appalachian District, 1965-73

\begin{tabular}{|c|c|c|c|c|c|c|c|c|}
\hline \multirow[b]{2}{*}{ Eastern Cities } & \multicolumn{2}{|c|}{ WV } & \multicolumn{2}{|c|}{ PA } & \multicolumn{2}{|c|}{ VA } & \multicolumn{2}{|c|}{$\mathrm{MD} * *$} \\
\hline & $\begin{array}{l}\text { Ave. An. } \\
\text { Unloads }\end{array}$ & $\begin{array}{l}\% \text { of } \\
\text { Total } \\
\end{array}$ & $\begin{array}{l}\text { Ave. An. } \\
\text { Unloads }\end{array}$ & $\begin{array}{l}\% \text { of } \\
\text { Total }\end{array}$ & $\begin{array}{l}\text { Ave. An. } \\
\text { Unloads }\end{array}$ & $\begin{array}{l}\% \text { of } \\
\text { Total }\end{array}$ & $\begin{array}{l}\text { Ave. An. } \\
\text { Unloads }\end{array}$ & $\begin{array}{l}\% \text { of } \\
\text { Total } \\
\end{array}$ \\
\hline Albany & 0 & 0 & 0 & 0 & 2 & $*$ & 0 & 0 \\
\hline Baltimore & 192 & 39 & 132 & 13 & 55 & 8 & 62 & 35 \\
\hline Boston & $*$ & $*$ & 3 & $*$ & 12 & 2 & 7 & 4 \\
\hline Buffalo & $*$ & $*$ & $*$ & $*$ & 3 & $*$ & 1 & $*$ \\
\hline New York-Newark & 21 & 4 & 155 & 16 & 205 & 30 & 13 & 7 \\
\hline Philadelphia & 83 & 17 & 248 & 25 & 152 & 22 & 27 & 15 \\
\hline Pittsburgh & 93 & 19 & 279 & 28 & 73 & 11 & 42 & 24 \\
\hline Providence & $*$ & $*$ & 0 & 0 & $*$ & $*$ & 0 & 0 \\
\hline Washington & 105 & 21 & 171 & 17 & 178 & 26 & 24 & 14 \\
\hline Total East & 497 & 65 & 989 & 80 & 679 & 45 & 176 & 58 \\
\hline Total Season & 766 & & 1236 & & 1509 & & 302 & \\
\hline
\end{tabular}

*Less than 1

**Data for Maryland based on one year, 1965. After 1965, Maryland unloads for each city in the East were included in "other" unloads.

Source: Marketing Appalachian District Apples, Annual Summaries 1965-73. 
average annual unloads, respectively. West Virginia is the fourth most important individual state supplier in this market and accounts for 7 percent of the average annual unloads.

Philadelphia. Unloads ranged from 1,477 in 1971 to 2,036 in 1969 but tended downward from 1965 to 1973 (Figure 7). The State of Washington is the largest supplier followed by New Jersey, Pennsylvania, New York, and Virginia. West Virginia ranks sixth by accounting for 4 percent of the average annual unloads. Although there is a downward trend in total unloads, there appears to be an upward trend in West Virginia unloads in this city.

\section{Monthly Unloads}

Baltimore. Although annual unload data showed West Virginia as the major shipper of apples into the Baltimore market, average monthly unload data indicate that the degree of importance varies during the year (Figure 8). From July through October, unloads of West Virginia apples increased. After October the trend of unloads was downward. In October the state accounts for 40 percent of the reported unloads, but in June only about 1 percent. The monthly unload pattern from other states in the District (Pennsylvania, Virginia, and Maryland) is essentially the same as West Virginia. Beginning in November and December, unloads from Washington and "other" states start increasing to fill the void created by reduced shipments from the District. For example, in October the District ships to Baltimore 80 unloads as contrasted to Washington's 5. By June the District ships only 3, but Washington ships 21 .

Washington, D. C. Shipments peak in October with 107 unloads reported and then decline to 44 in June (Figure 9). In October the District accounts for approximately 84 percent of the unloads, but by June only 12 percent. Shipments from the State of Washington fill the greatest part of the void created by smaller District shipments. In October, Washington unloads accounted for 6 percent of shipments and by June, 70 percent. September and October are the most important months for West Virginia apples. During these months the state accounts for 28 and 15 percent, respectively, of the total unloads reported.

Pittsburgh. In the Pittsburgh market the reported shipments reach a peak of 140 unloads in October and decline to 66 by June (Figure 10). This rate of decline is slower than the rate of decline in Baltimore or Washington. In September and October the District accounts for 65 and 61 percent, respectively, with the proportion declining to less than 3 percent by June. As Appalachian shipments decline from September to June, the void in the market is filled by New York and Washington apples. September and October are the most important months for West Virginia apples. By April there are hardly any shipments to Pittsburgh.

Philadelphia. Unloads reach a peak of 205 in October and then decrease to 91 by June (Figure 11). The District accounts for 44 percent of the October 
unloads and Washington, New York, and New Jersey account for 11, 10, and 29 percent, respectively. By July the Appalachian proportion has dropped to 6 percent and Washington, New York, and New Jersey proportions account for 63, 12 , and 11 percent. Although October is the most important month, this market does not use as many West Virginia apples each year as the Baltimore, Washington, and Pittsburgh markets.

\section{Annual Per Capita Unloads}

Baltimore. From 1965 to 1973 annual average unloads were 12.7 pounds per capita (Figure 12). Except for 1969, the annual per capita unlaods have declined each year from a high of 14.9 pounds in 1965 to 8.2 pounds in 1973 .

Washington, D. C. From 1965 to 1973 the average annual unloads were 11.5 pounds per capita (Figure 13). Although this is 1.2 pounds below the average per capita unloads in Baltimore, the per capita unloads in Washington were more stable from 1965-73. None of the years had a per capita unload of less than 10 pounds.

Pittsburgh. From 1965 to 1973 average annual per capita unloads were 18.5 pounds (Figure 14). This was the highest of the four markets studied. Annual per capita unloads in Pittsburgh reached a peak in 1968 and then declined for the next three years before leveling out for 1972 and 1973.

Philadelphia. From 1965 to 1973 average annual per capita unloads were 13.4 pounds (Figure 15). Although the unloads from 1965 through 1969 were larger than from 1970 through 1973, the per capita unloads in the market have remained fairly close to 12 pounds per year.

\section{Monthly Per Capita Unloads}

Baltimore. Average monthly per capita unloads from 1965 through 1973 start at approximately .40 pound in July, reach a peak of 1.62 pounds in October, and decline to .59 pound by June (Figure 16). The range (difference between maximum and minimum) was largest in October and smallest in August. October is also the month with the largest per capita unloads while August is the lowest.

Washington, D. C. Per capita unloads are the lowest in August, .3 pound, and reach a peak of 1.38 pounds in October (Figure 17). The largest range occurs in September, the smallest range in August.

Except for July and April, the monthly per capita unloads were less than Baltimore.

Pittsburgh. Smallest monthly per capita unloads of .80 pound occurred in July; the largest in October when 2.10 pounds were unloaded (Figure 18). Except for June, July, and August, monthly per capita unloads exceeded 1.5 pounds each month and remained relatively stable from September through 
May. The largest and smallest range in unloads occurred in September and July, respectively.

Philadelphia. Monthly per capita unloads increased from .42 pound in July to 1.52 pounds in October (Figure 19). Except for June, July, and August they remained fairly stable and above 1.0 pound for each month. The largest range occurred in December and the smallest in July.

\section{Prices}

Complete price quotations for specific varieties and grades of apples by city and origin are not available. However, the Bureau of Labor Statistics publishes monthly Estimated Retail Food Prices by Cities. This report provides only estimated retail prices for all apples in several cities, but a comparison of prices among cities should reflect supply-demand situations and be useful to producers and brokers in making marketing decisions.

Average Annual Prices. Except for the decrease in 1969 and 1970, estimated retail price of all apples in the four cities (Baltimore, Philadelphia, Pittsburgh, and Washington, D. C.) increased annually from around 17 cents per pound in 1965 to approximately 32 cents in 1973 (Figure 20). Although prices in Pittsburgh moved upward most years, they were well below the prices in the other three cities.

Average Monthly Prices. Average monthly prices in all four cities show the expected seasonal pattern. Prices reach peaks in July and August, decline through November, and then increase through June (Figure 21). Although prices in Baltimore, Philadelphia, and Washington are similar in magnitude throughout the year, the average Baltimore monthly price is above Philadelphia and Washington prices from August through November and then falls below from January to June. Average monthly retail prices in Pittsburgh were below prices in the other cities every month. Relationships in Figure 21 suggest Philadelphia as the highest priced market for apples marketed from August through November. After November Philadelphia and/or Washington becomes the higher priced markets. 


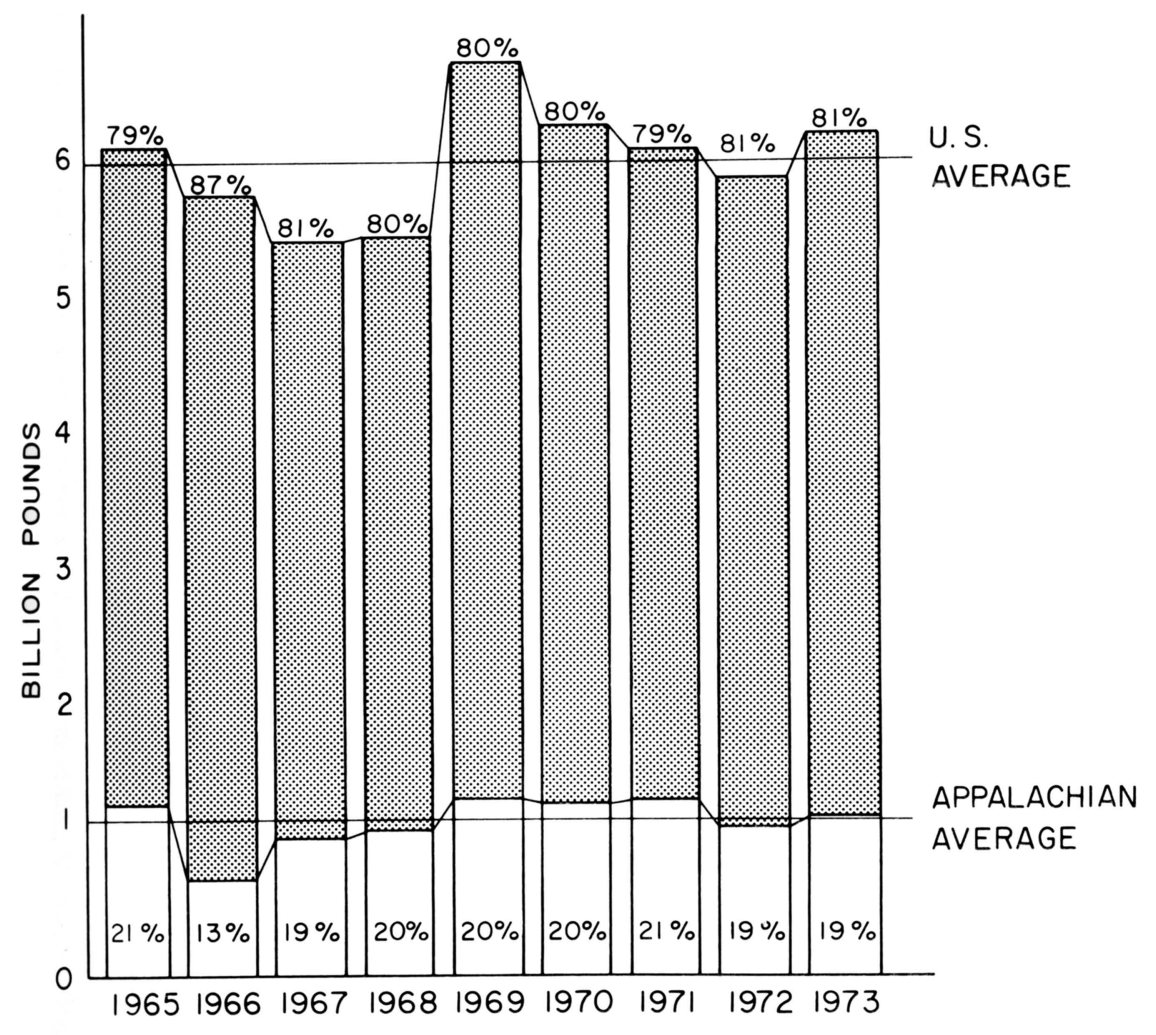

Figure I. Commercial Apple Production, U. S. and Appalachian District, 1965-73 


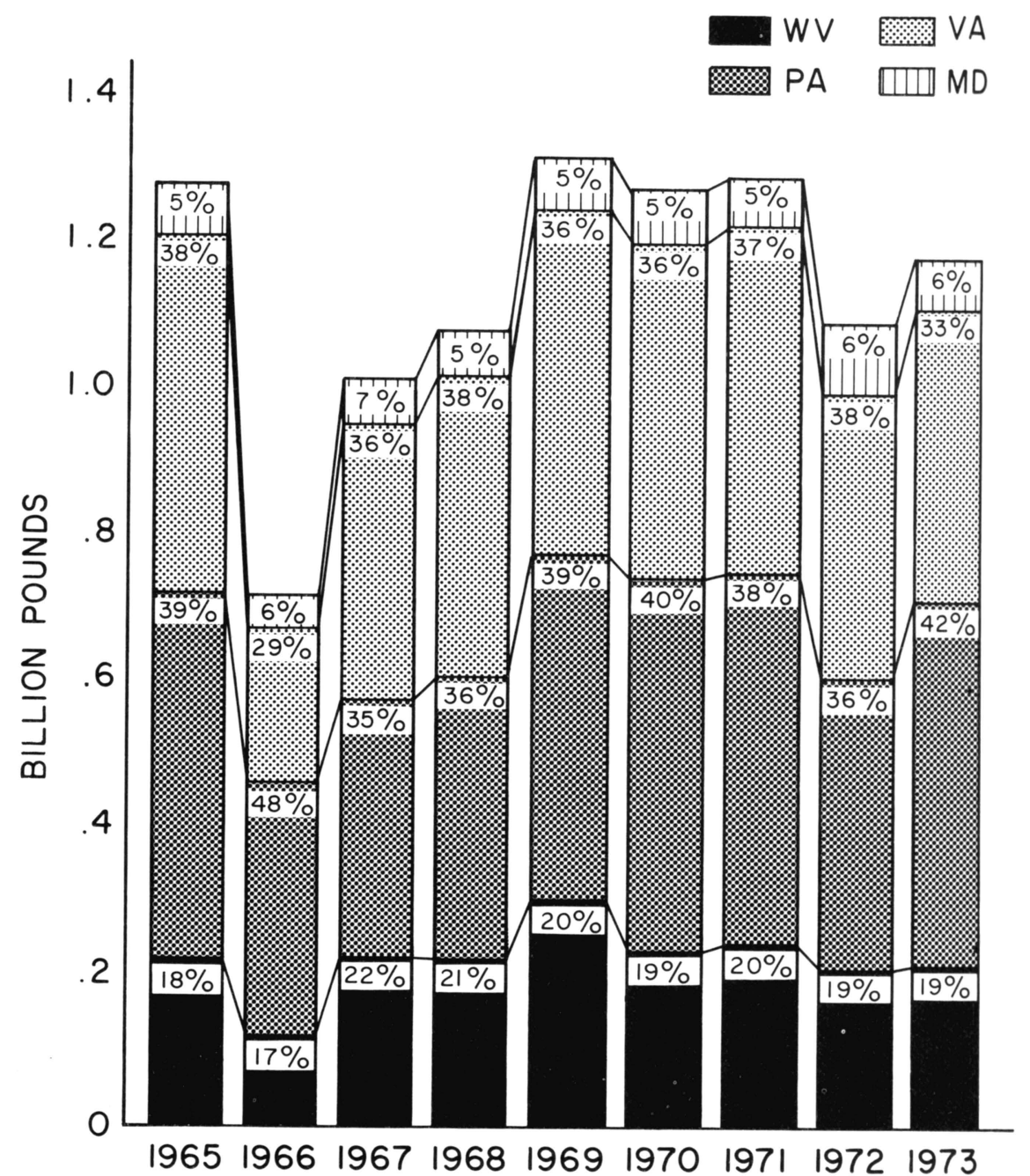

Figure 2. Commercial Apple Production in Appalachian District by State and Percentage, 1965-73 
Midwest

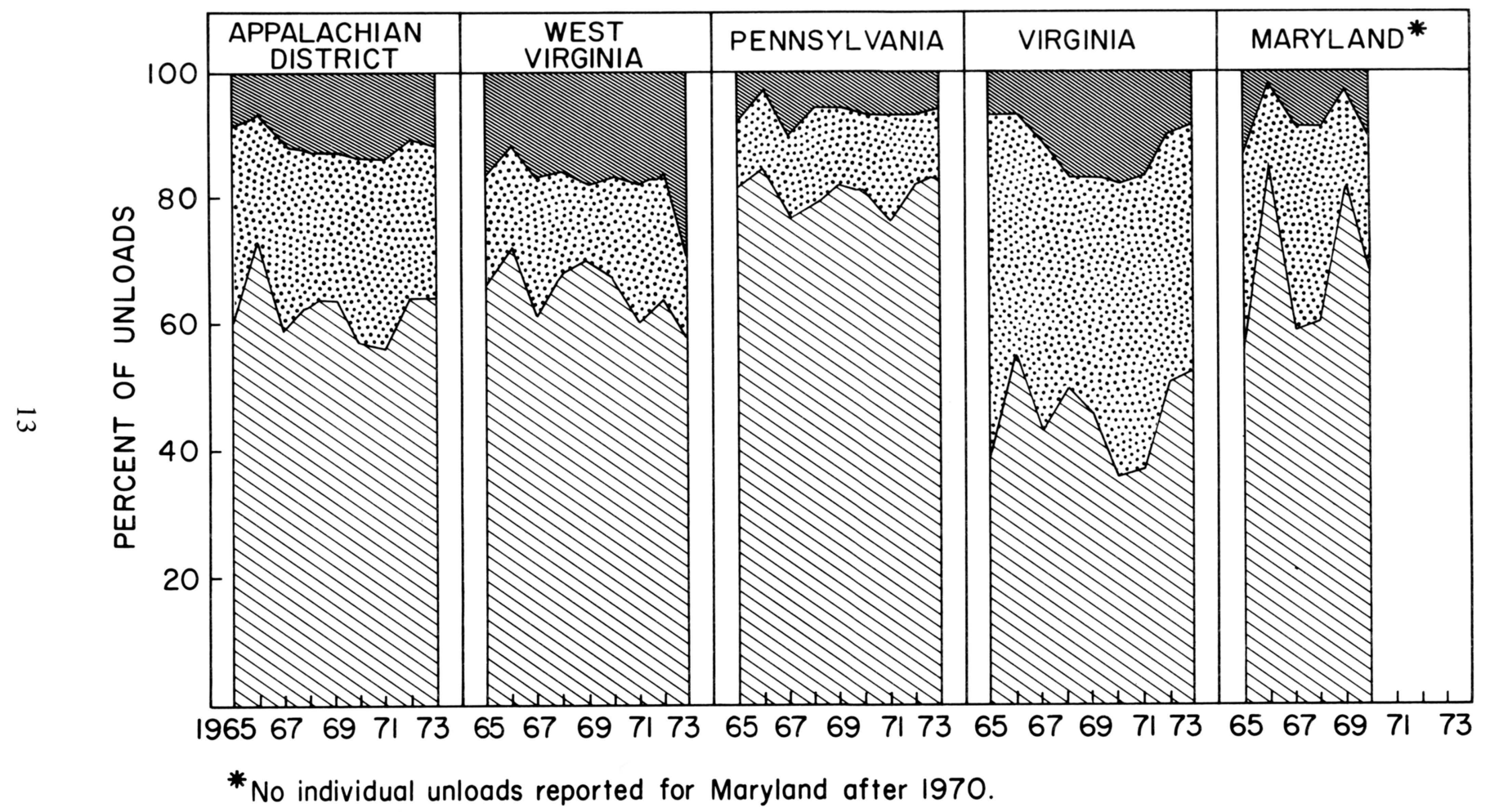

Figure 3. Unloads Reported for Appalachian District and States by Markets, 1965-73 


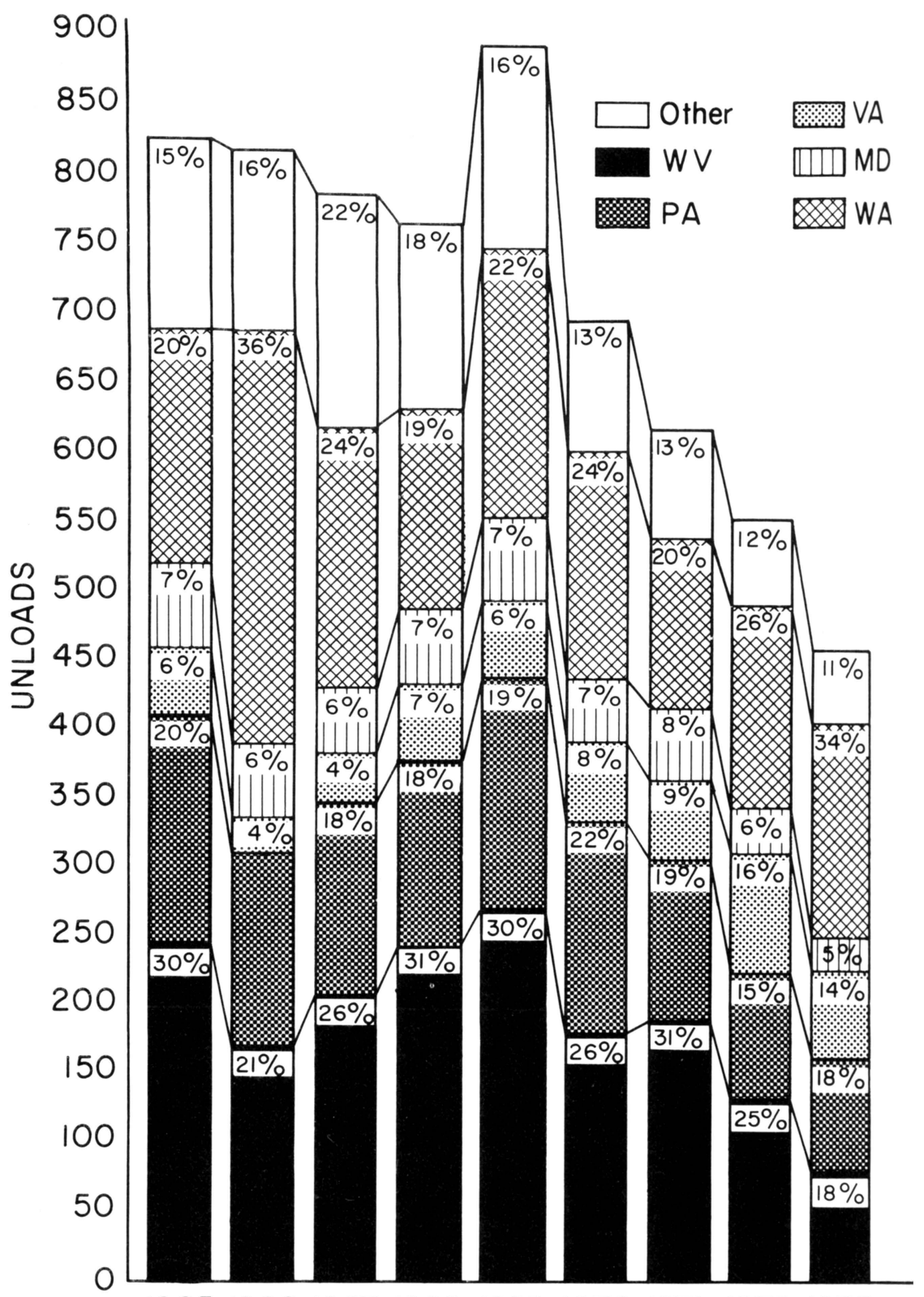

$\begin{array}{llllllllll}1965 & 1966 & 1967 & 1968 & 1969 & 1970 & 197 \mid & 1972\end{array}$

Figure 4. Apple Unloads in Baltimore by Origin and Percentage, 1965-73 


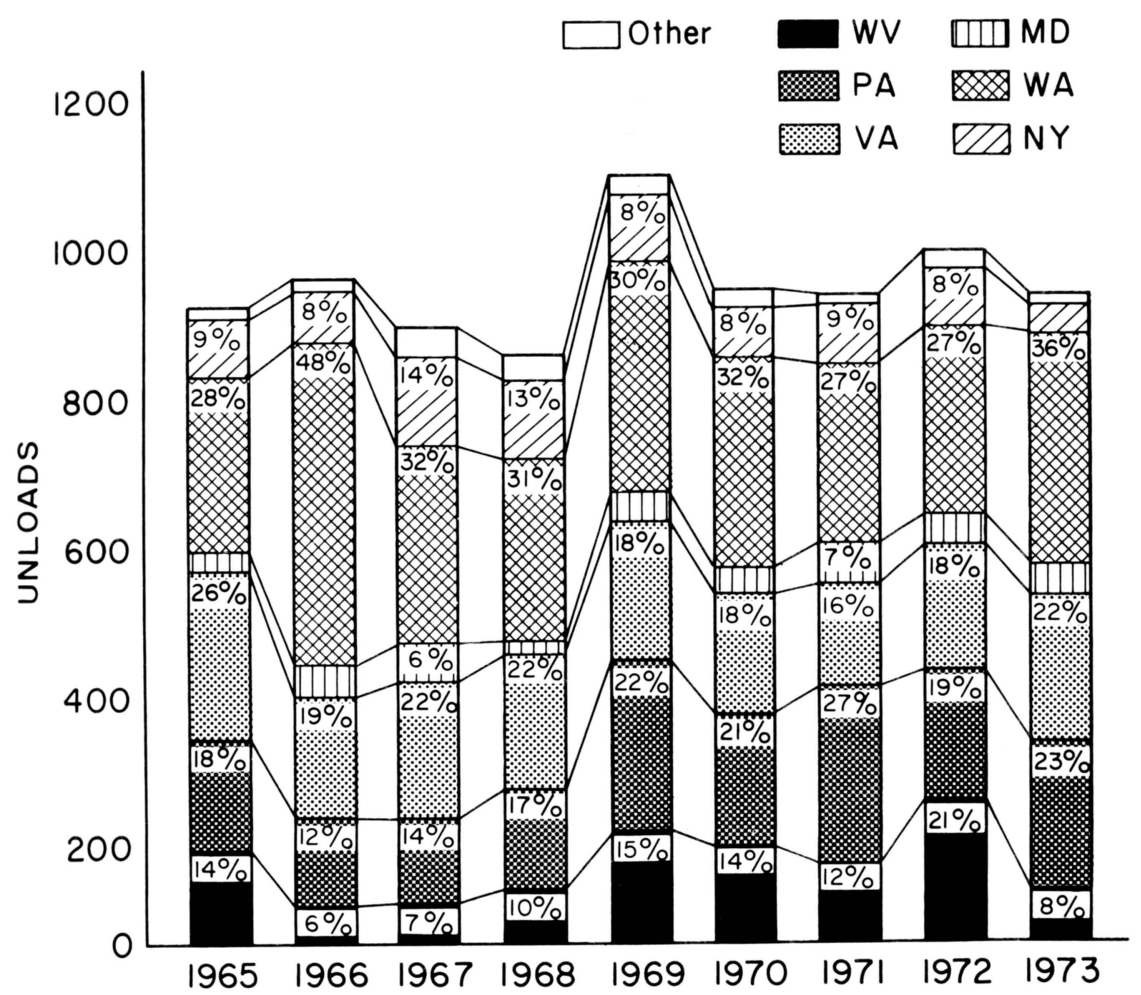

Figure 5. Apple Unloads in Washington, D.C. by Origin and Percentage, $1965-73$

* Unmarked areas are less than $6 \%$ 


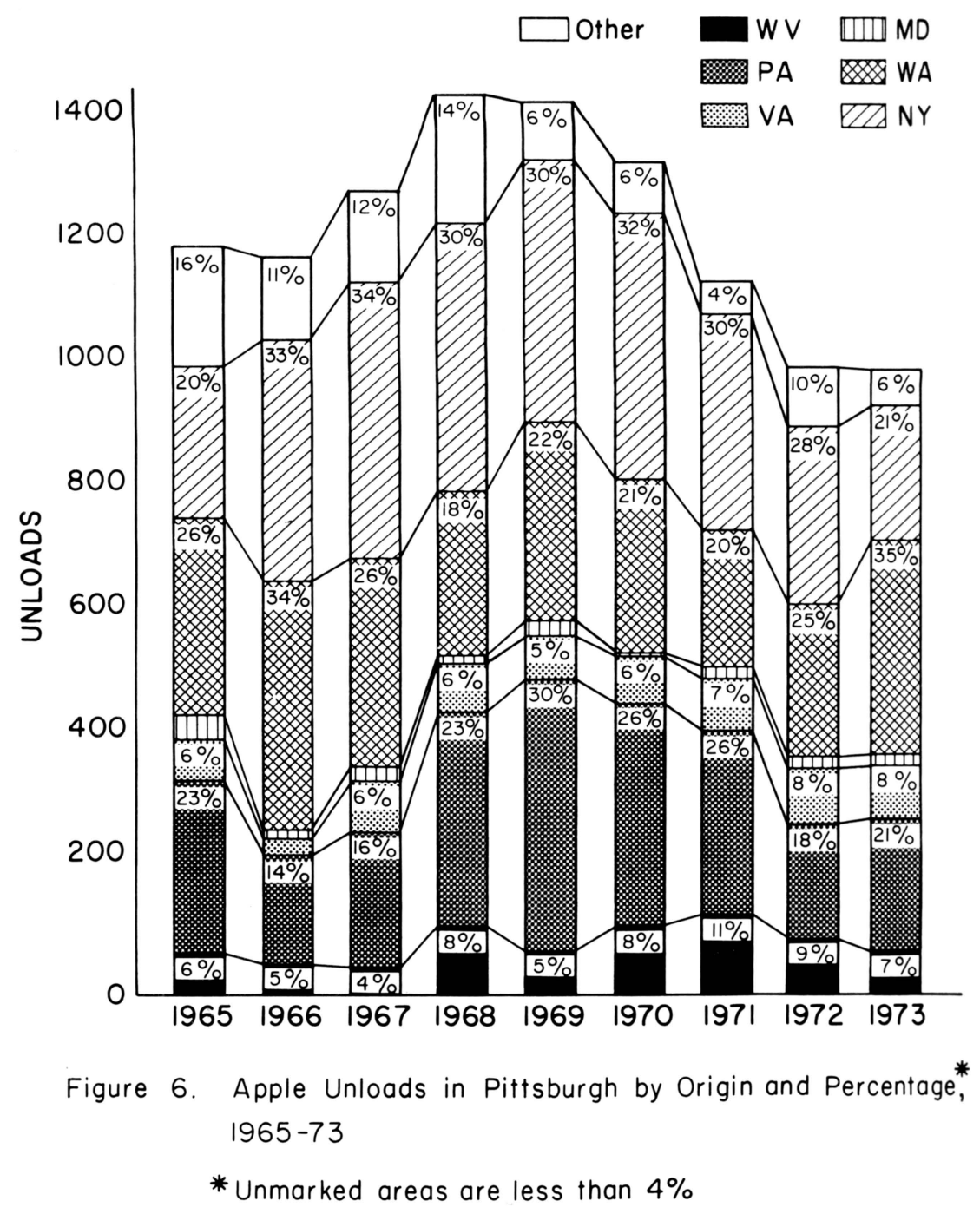




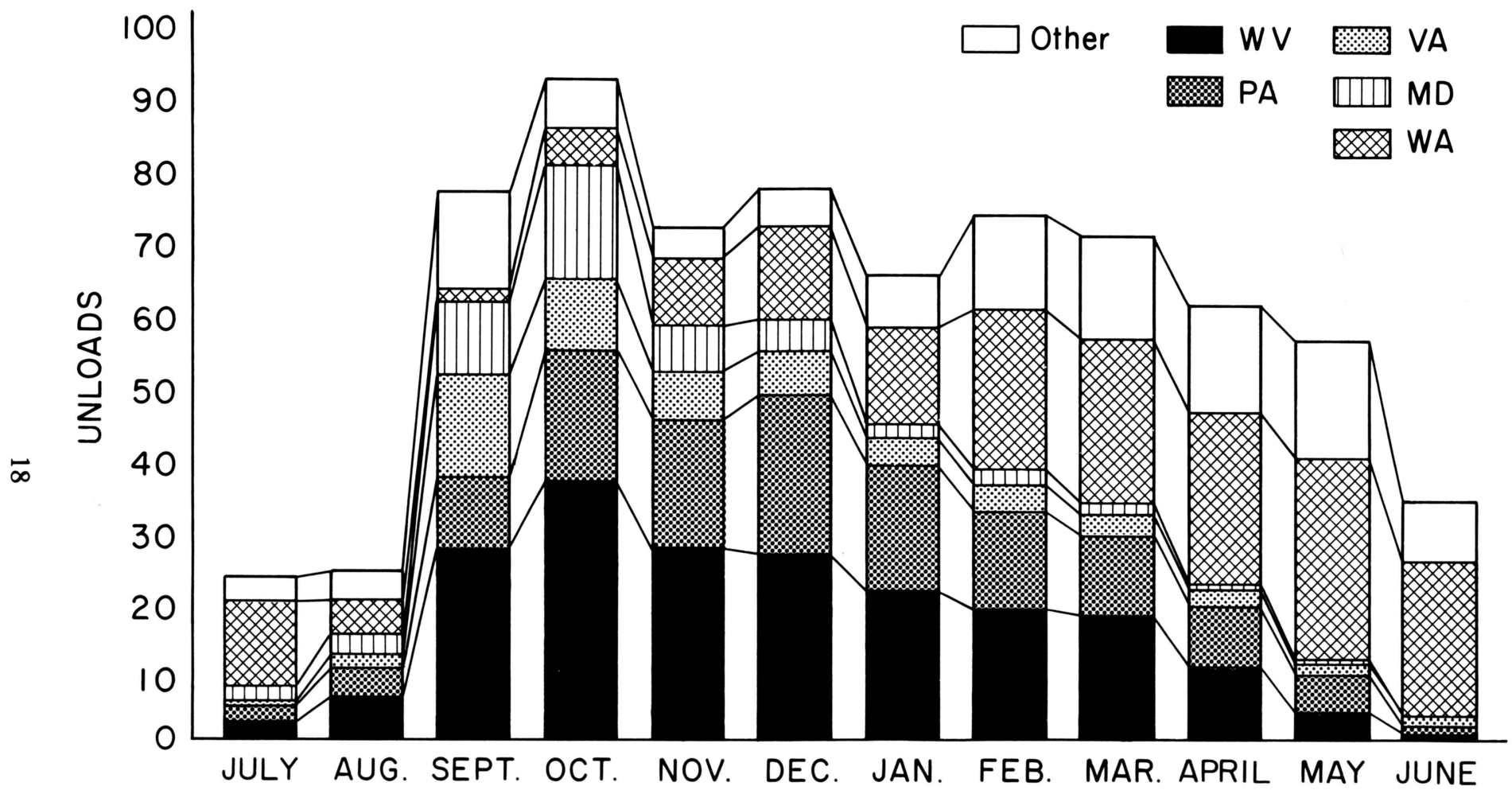

Figure 8. Average Monthly Unloads of Apples in Baltimore by Origin, 1965-73 


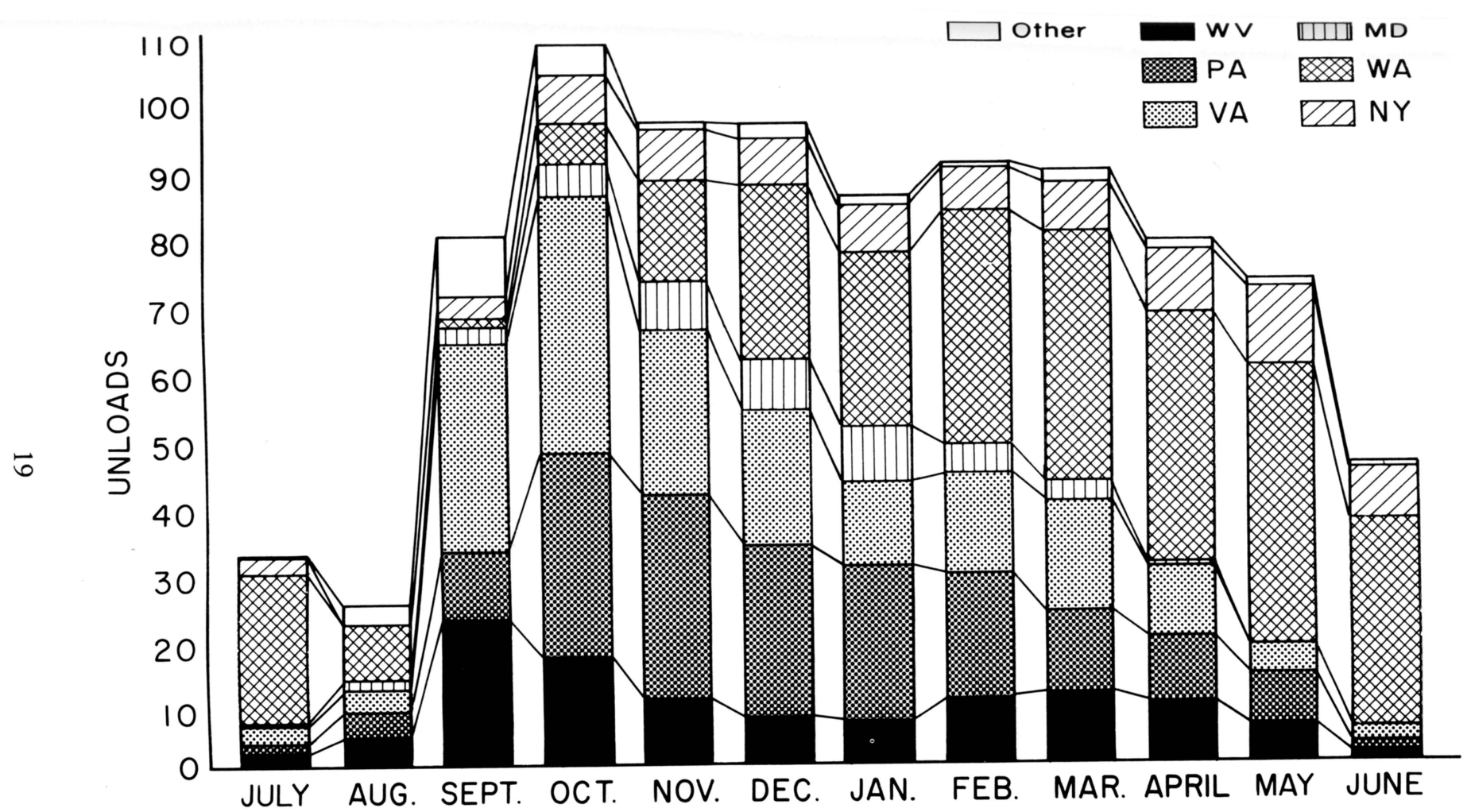

Figure 9. Average Monthly Unloads of Apples in Washington, D.C. by Origin, 1965-73 


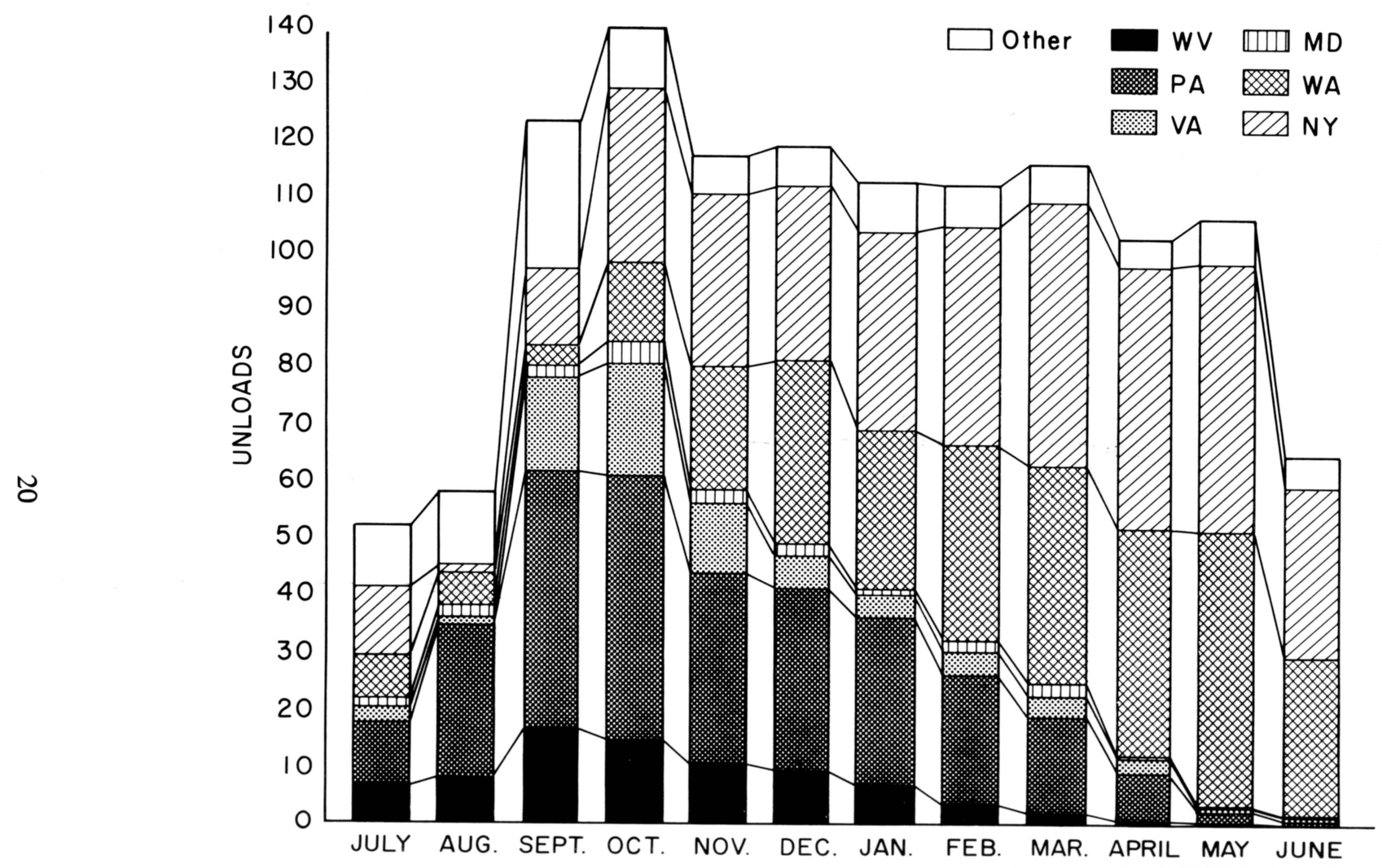

Figure 10. Average Monthly Unloads of Apples in Pittsburgh by Origin, 1965-73 


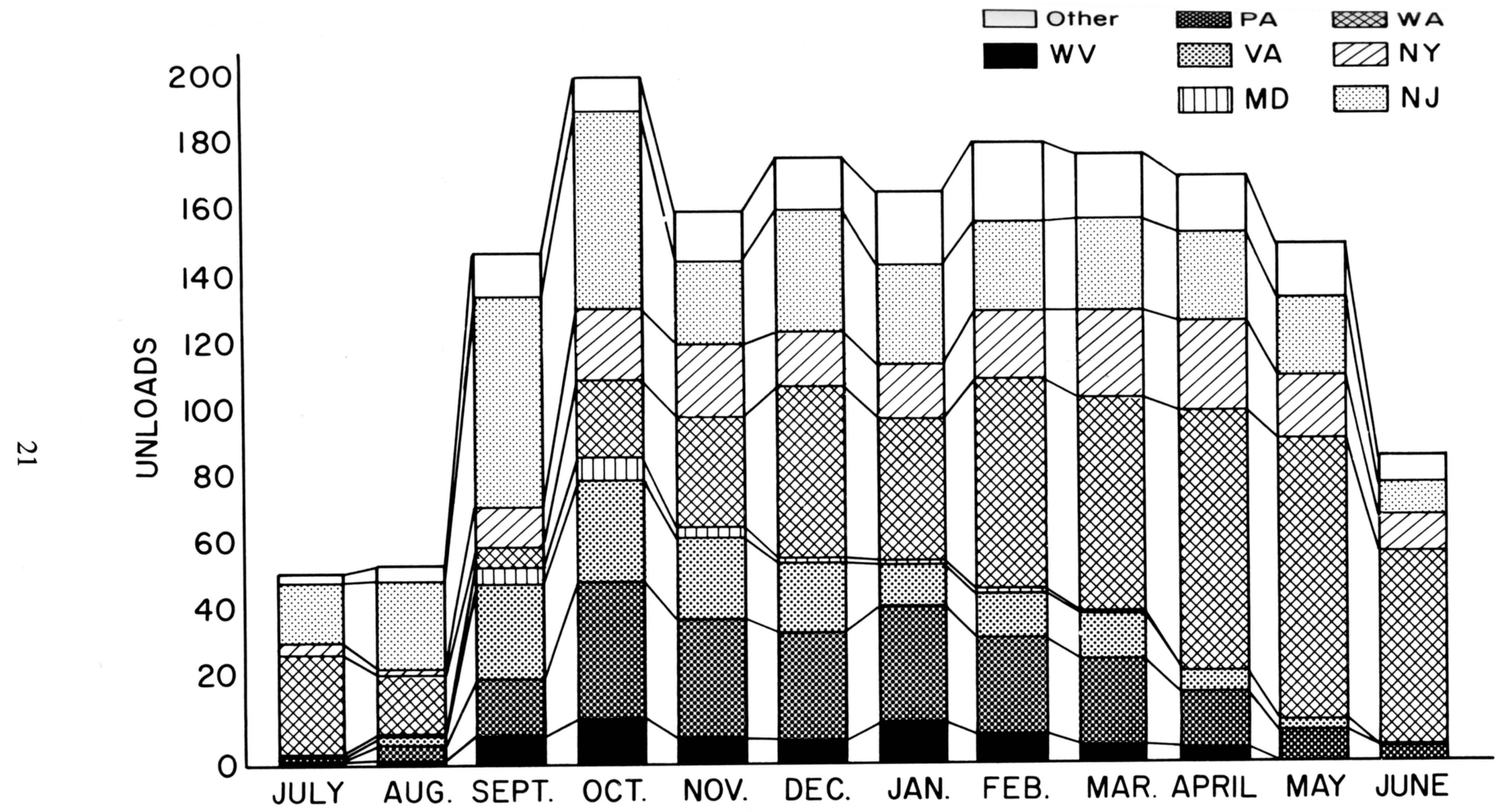

Figure II. Average Monthly Unloads of Apples in Philadelphia by Origin, 1965-73 


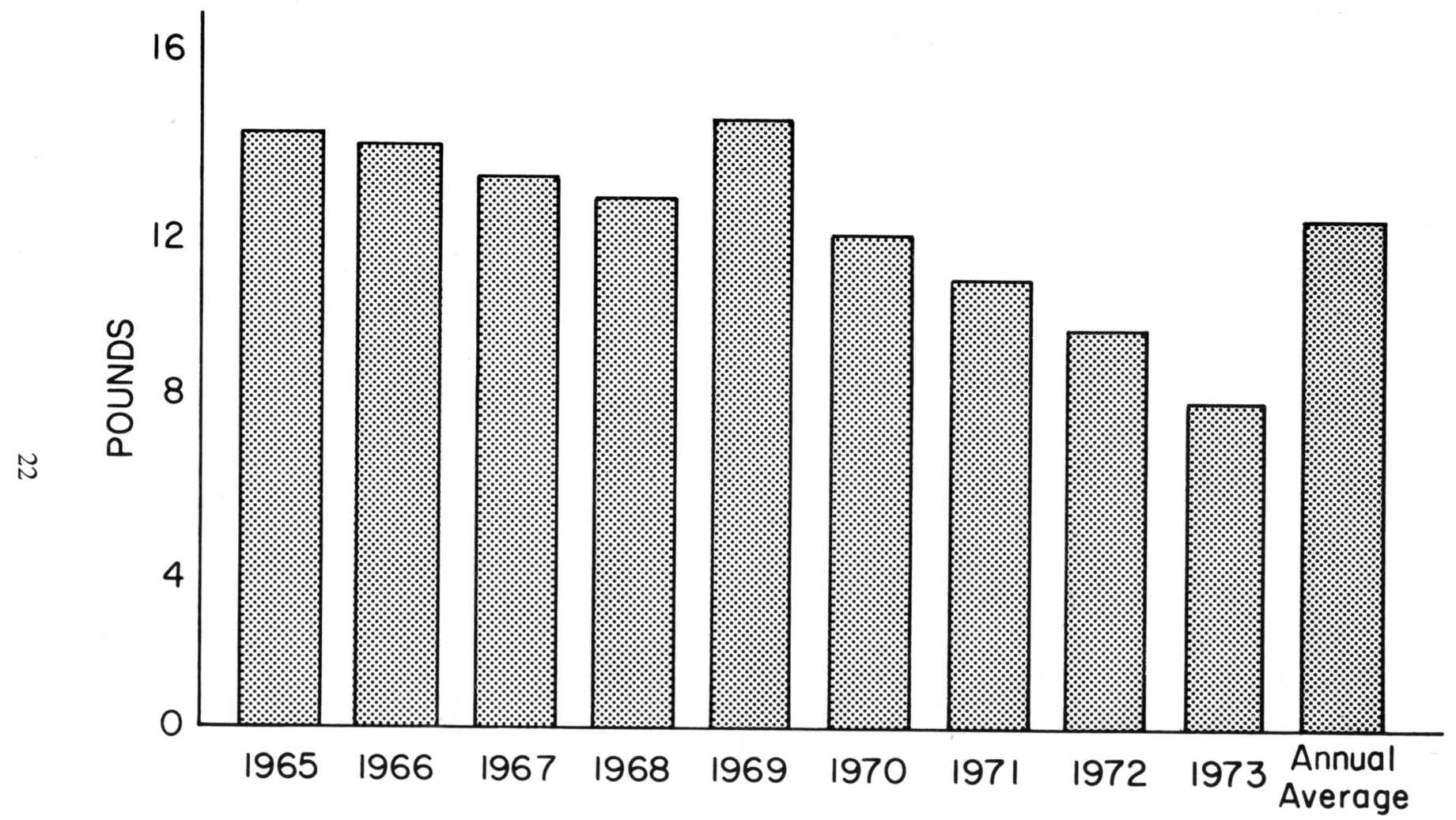

Figure 12. Annual Per Capita Unloads of Apples in Baltimore.1965-73 


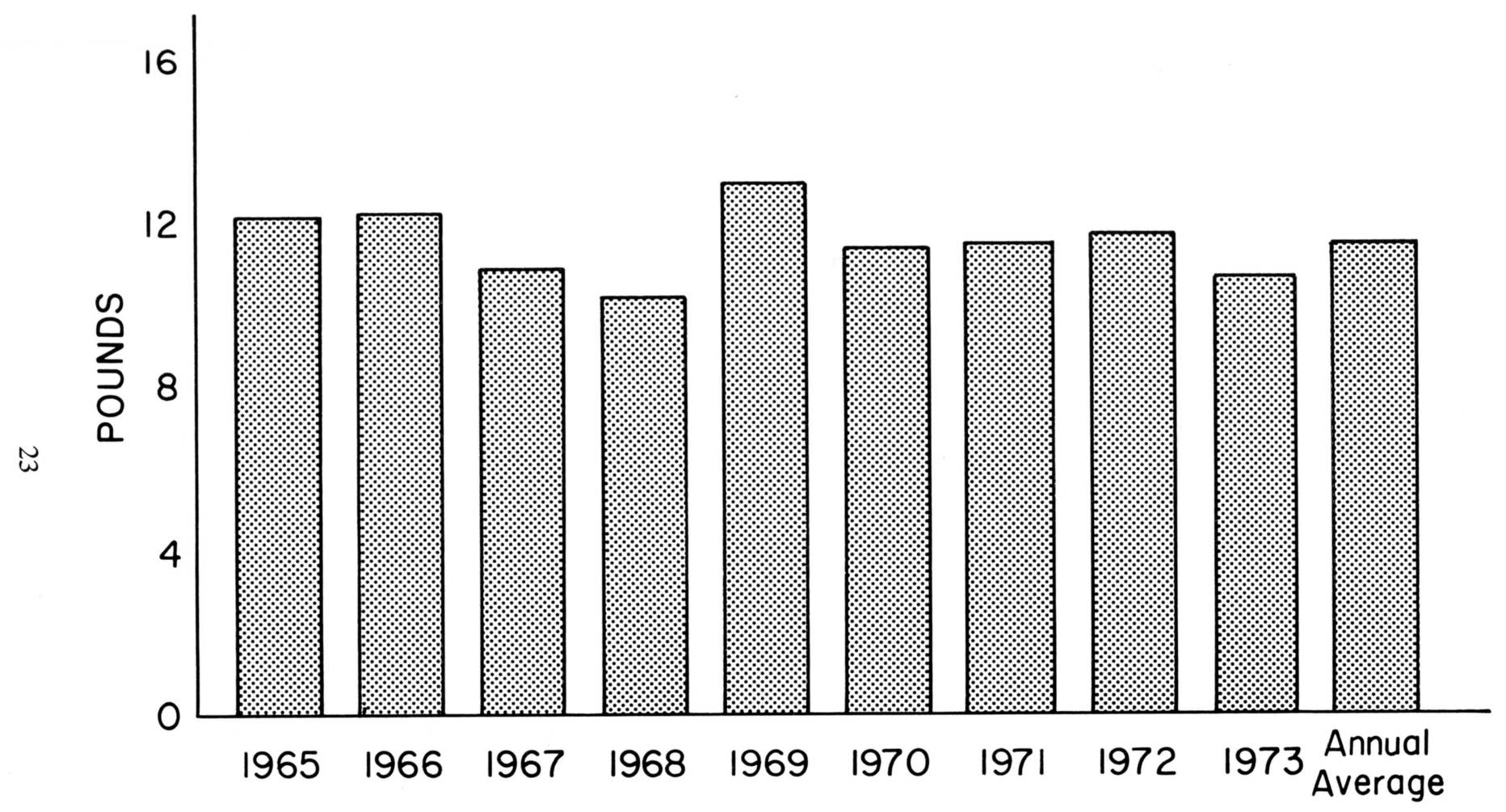

Figure 13. Annual Per Capita Unloads of Apples in Washington, D.C., 1965-73 


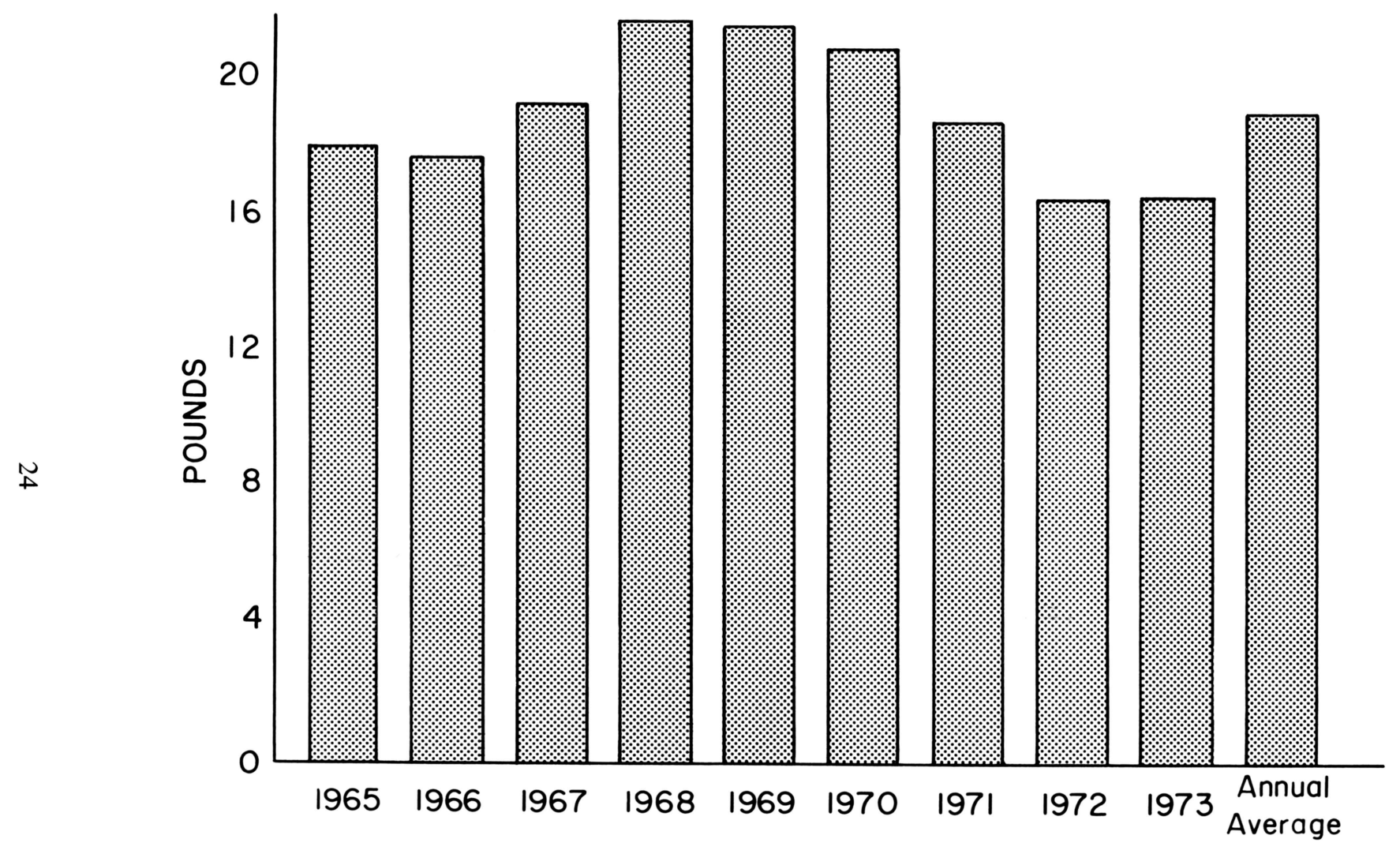

Figure 14. Annual Per Capita Unloads of Apples in Pittsburgh, 1965-73 


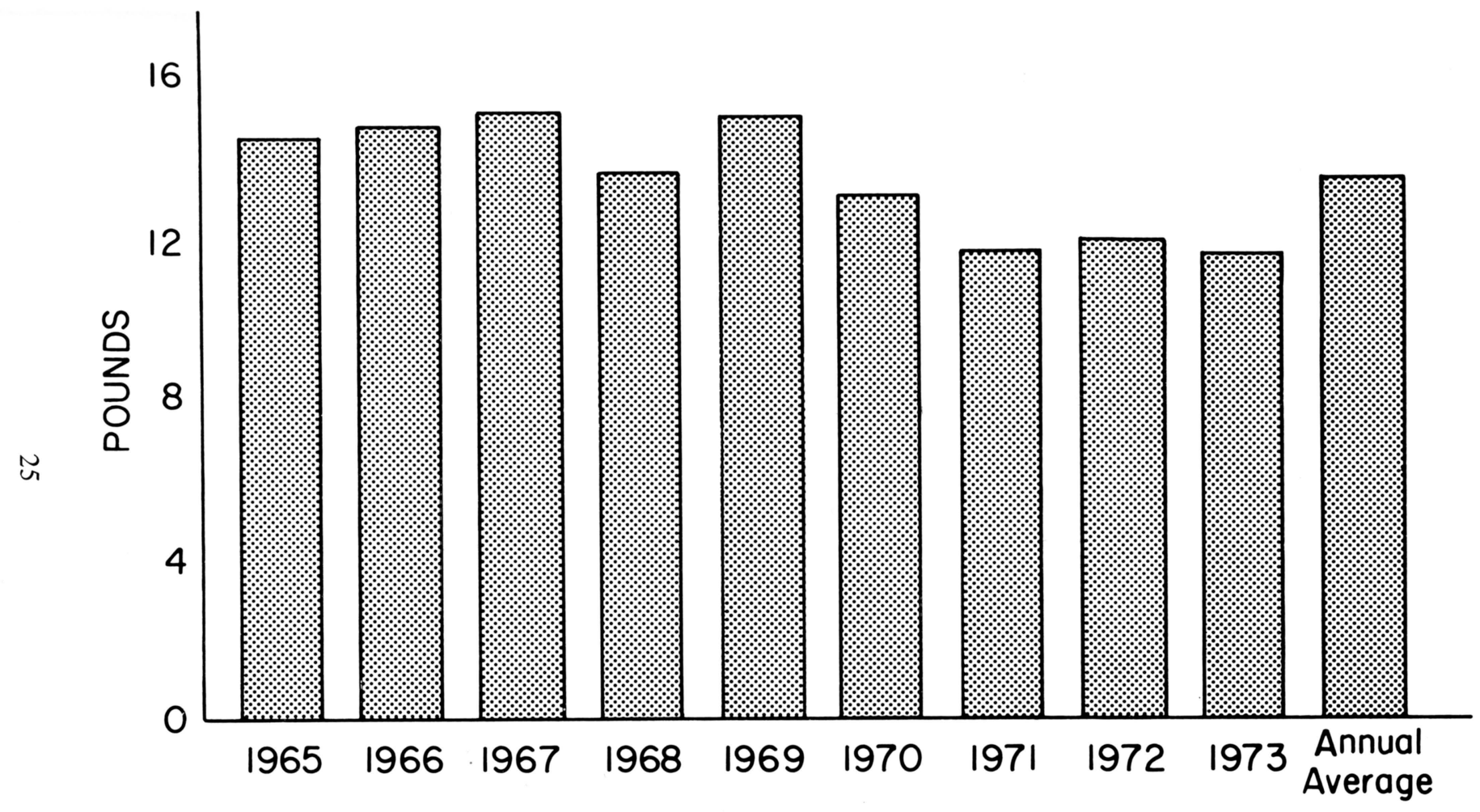

Figure 15. Annual Per Capita Unloads of Apples in Philadelphia, 1965-73 


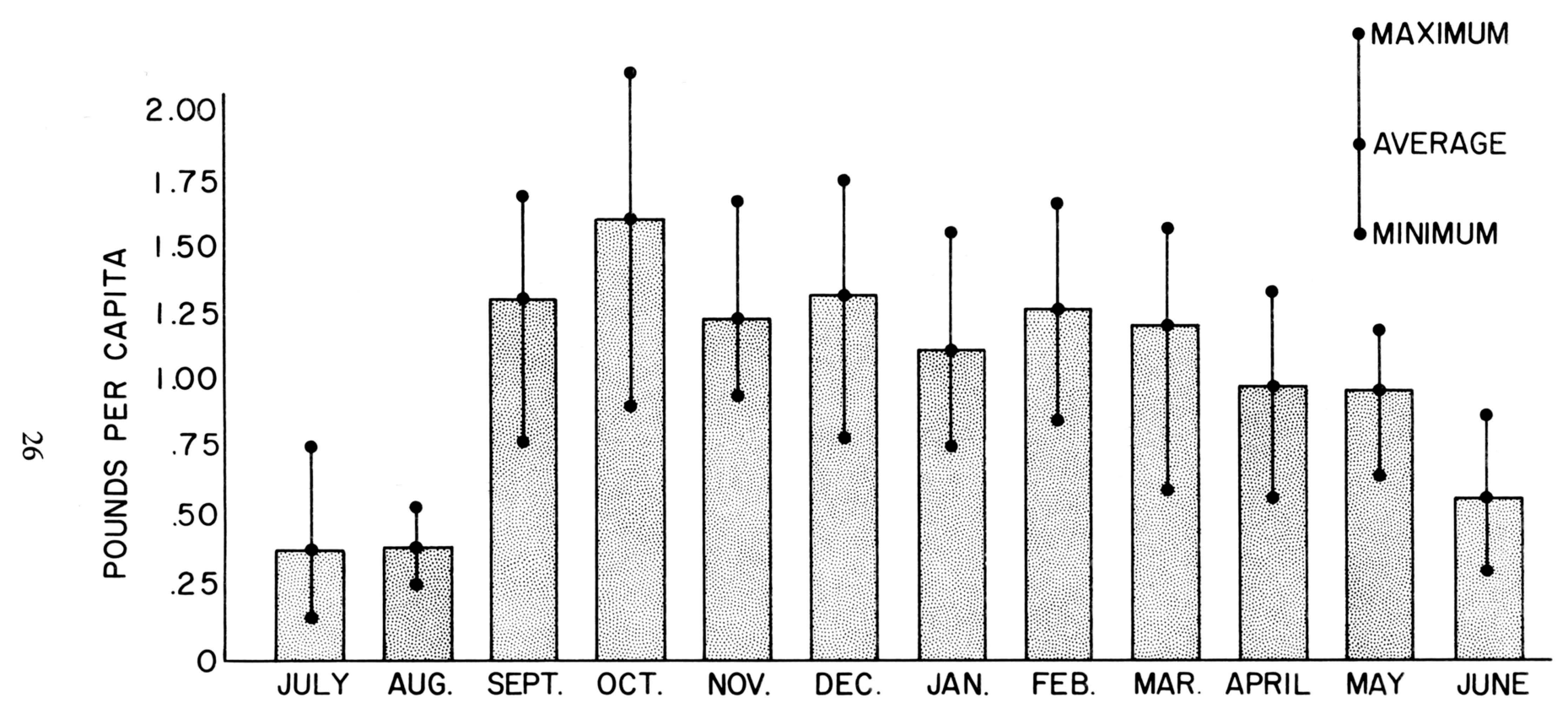

Figure 16. Average, Maximum, and Minimum Monthly Unloads of Apples Per Capita in Baltimore, $1965-73$ 


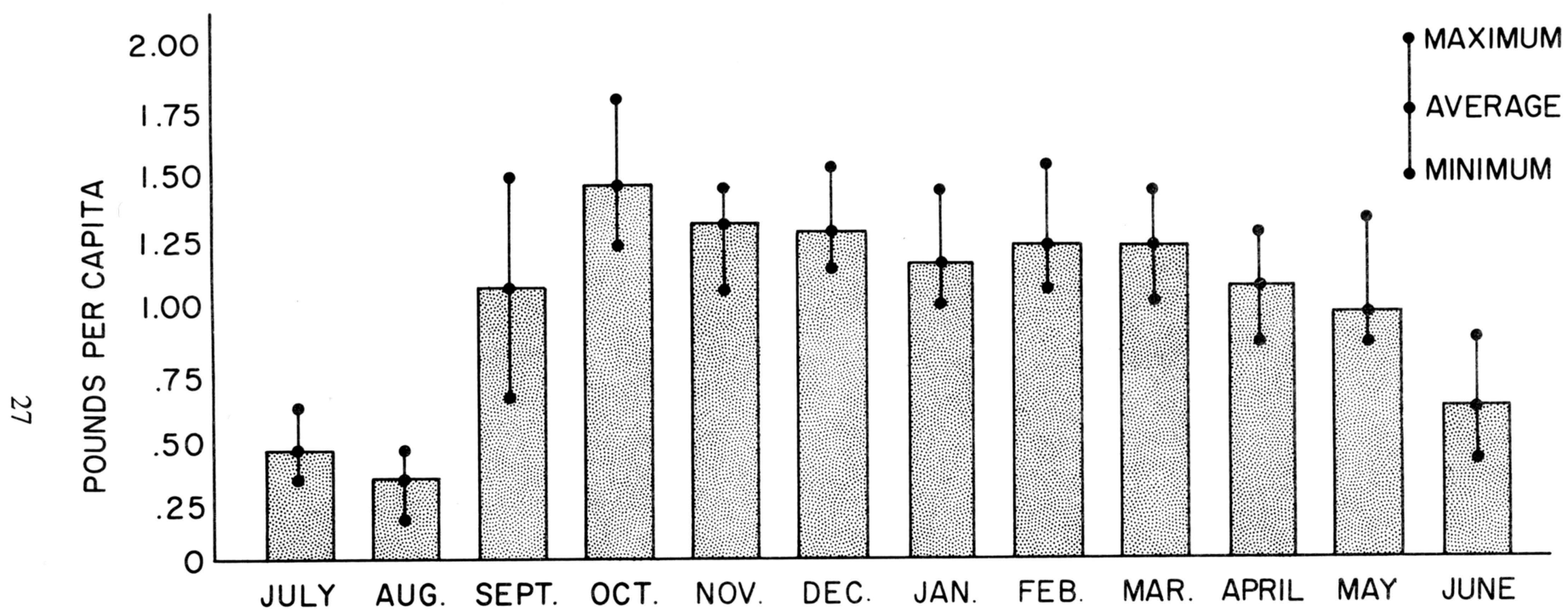

Figure 17. Average, Maximum, and Minimum Monthly Unloads of Apples Per Capita in Washington, D. C. , $1965-73$. 


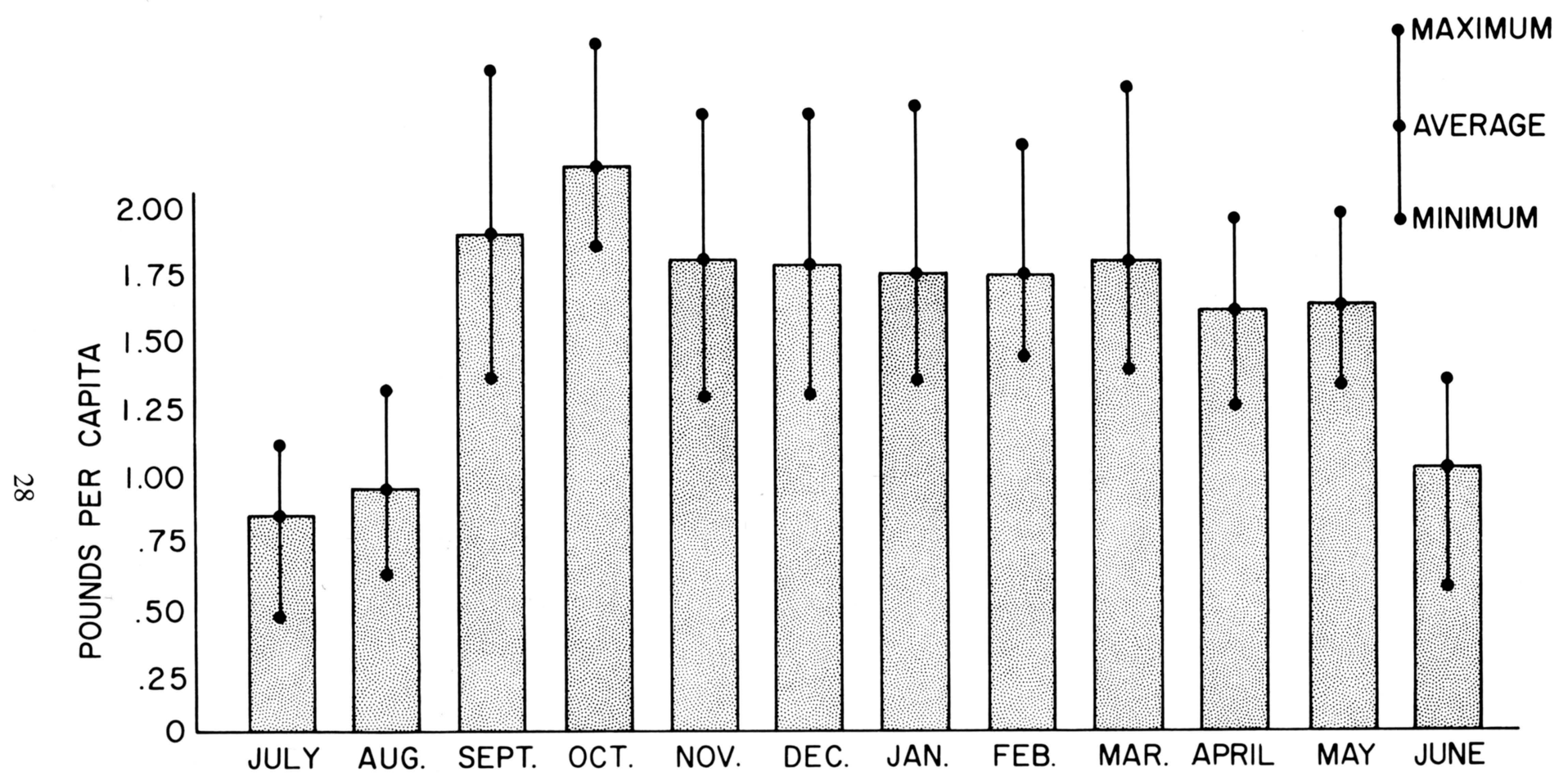

Figure 18. Average, Maximum, and Minimum Monthly Unloads of Apples Per Capita in Pittsburgh, 1965-73 


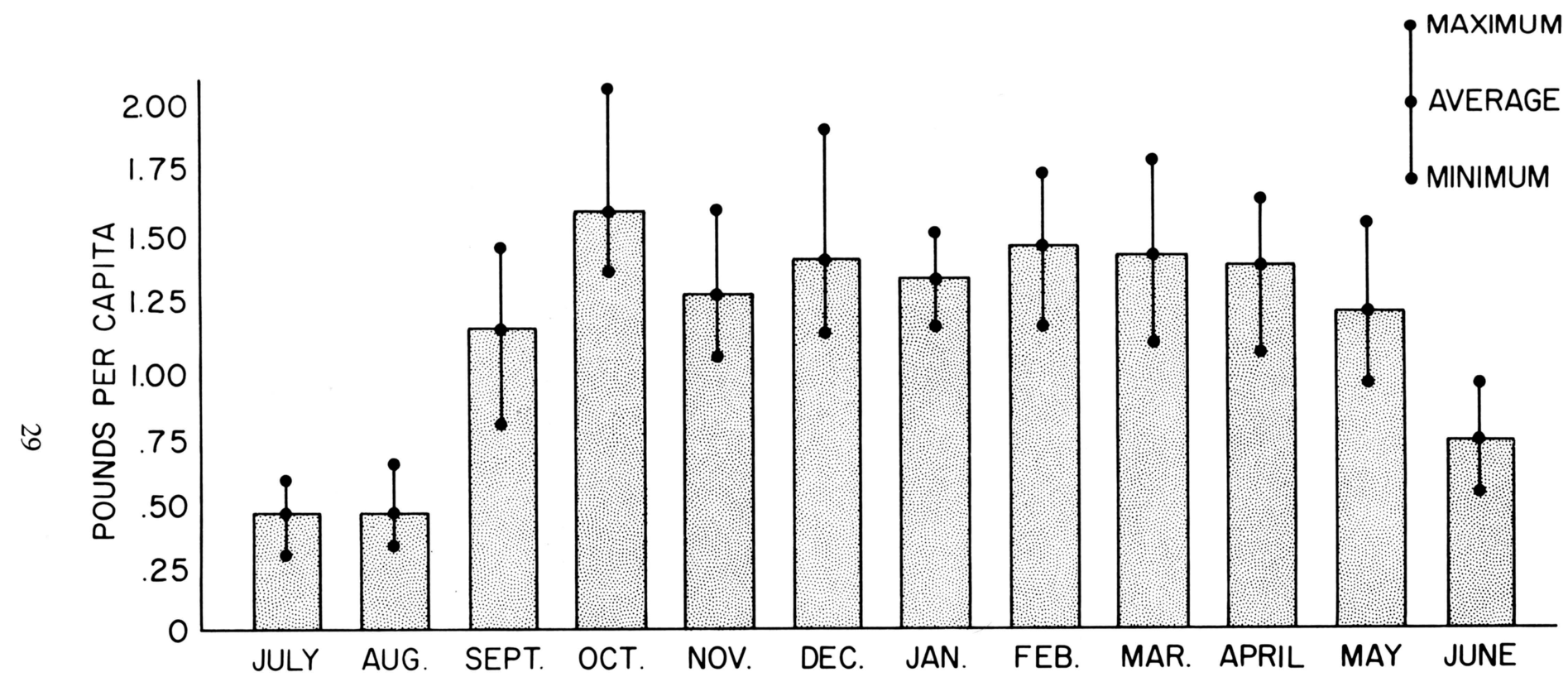

Figure 19. Average, Maximum, and Minimum Monthly Unloads of Apples Per Capita in Philadelphia, 1965-73 


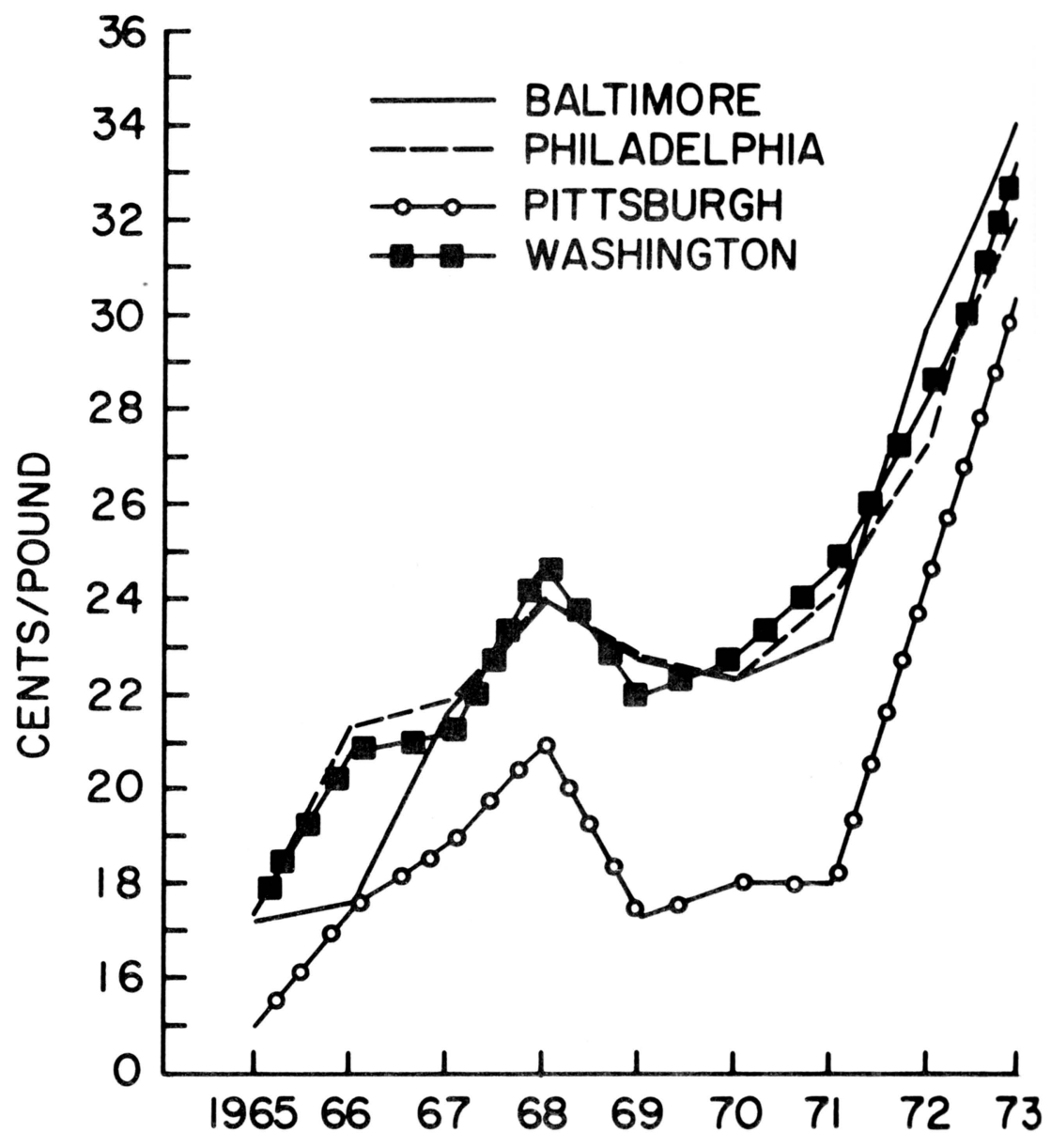

Figure 20. Average Annual Retail Price of Apples in Four Cities, 1965-73 


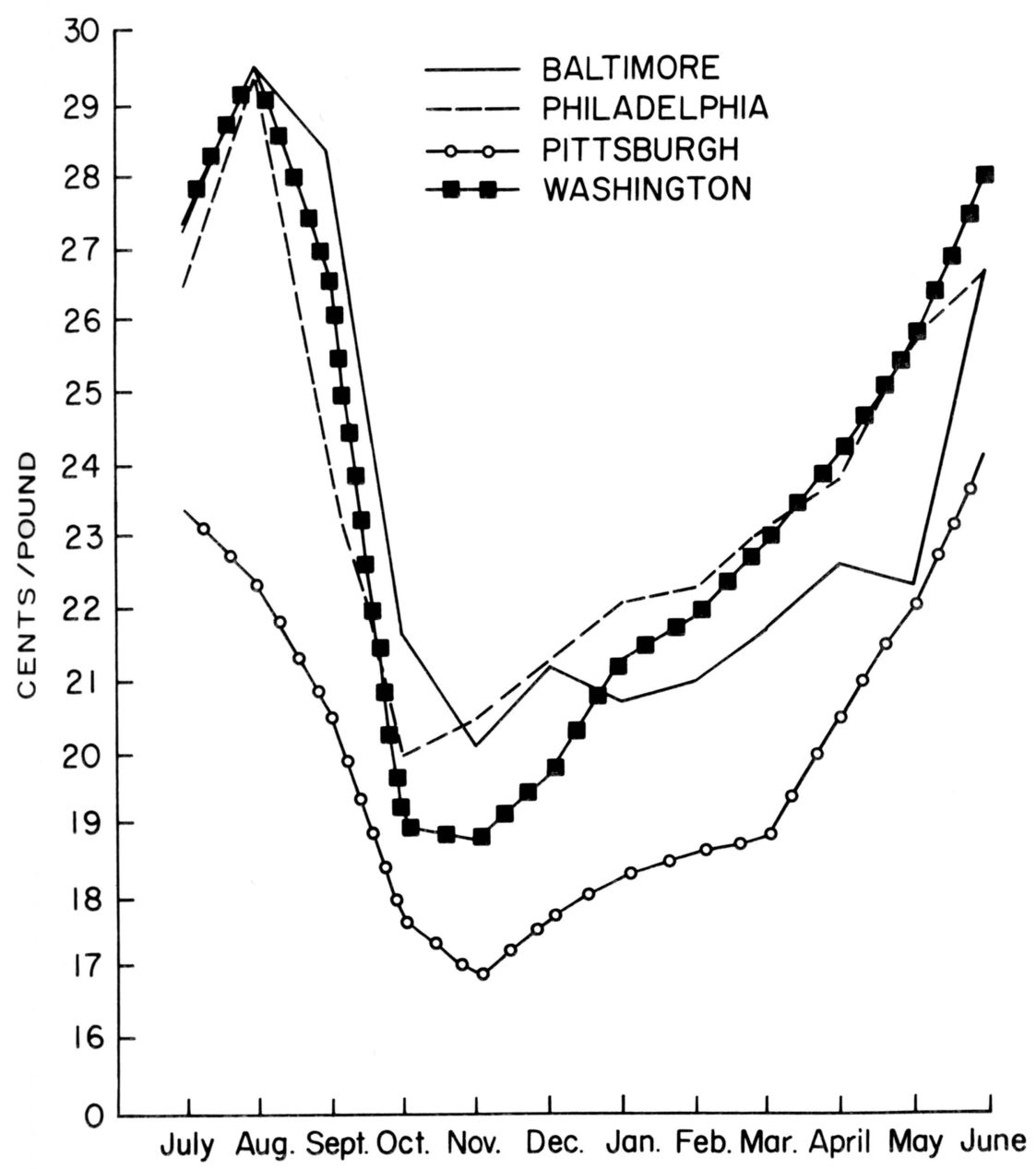

Figure 21. Monthly Average Price Per Pound of Apples in Cities, 1965-73 
Blank Page in Original Bulletin 
Blank Page in Original Bulletin 
Blank Page in Original Bulletin 